\title{
Jacob Lestschinsky: A Yiddishist Dreamer and Social Scientist
}

\section{Gennady Estraikh}

New York University

\section{Argument}

Jacob Lestschinsky (1876-1966) emerged as the leading social scientist in pre-1917 circles of Yiddishist Marxist nationalists, most notably the Territorialists, who sought to create Jewish statehood outside Palestine. Lestschinsky played a central role in Jewish institutions formed in Ukraine in 1918-1920. A convinced anti-Bolshevik, he lived in Germany, then in Poland, America, and eventually in Israel. He combined two careers: a popular Yiddish journalist and an influential scholar. He conducted demographic and statistical studies under the auspices of the Yiddish Scientific Institute (YIVO) whose headquarters were in Vilna (Vilnius) until the beginning of World War II and were later moved to New York. Lestschinsky was one of the fathers of YIVO and was associated with the organization until the 1950s. In January 1945, during a YIVO conference in New York, he was the first to estimate the number of Holocaust victims as six million. This article analyzes Lestschinsky's theoretical outlook and its transformation under the influence of the vicissitudes of Jewish life.

\section{From Talmud to Marxism}

This article analyzes Jacob (Yakov) Lestschinsky's (26 August 1876 - 20 March 1966) contribution to Yiddishist scholarship, which emerged at the beginning of the twentieth century as part of Jewish national projects advanced by several ideological currents. ${ }^{1}$ One of these, Territorialism, focused its attention on the issue of creating Jewish statehood outside Palestine (for Territorialism, see Patkin 1947; Steinberg 1954). In retrospect, Lestschinsky was called "the dean of Jewish sociologists" as well as "an outstanding practitioner in the fields of Jewish demography and statistics, social research, economic history, and historiography" (Glikson 1967, 48). Among East European Jewish radicals he and Ber Borochov, a key figure in the Labor Zionist movement, became pioneering Marxist theoreticians of Jewish nation-building (Manor 1961, 21). Both theoreticians belonged to the cohort of socially ambitious polymaths (some

\footnotetext{
${ }^{1}$ Even against the background of notoriously inconsistent spellings of Yiddish authors' names, Lestschinsky is arguably unsurpassed: Leshtshinsky, Leschinsky, Leshchinsky, Leshtsinsky .... In this article, the spelling Lestschinsky will be used following the Library of Congress, especially as this form appears most frequently in English and German publications.
} 
of them autodidacts with a smattering of systematic non-religious education) who dominated Jewish ideological debates at the turn of the twentieth century, combining their political activities with journalism and scholarship.

Small wonder then that such activists' scholarship often had a political side. In his 1913 article, "The Tasks of Yiddish Philology," Borochov defined philology as an academic field, populated by ideologically committed scholars. In the footnote to the very first paragraph of his seminal work, he made clear the difference between linguistics and philology. "Linguistics is a general science, whereas philology is a national one [science]." According to Borochov, "A person who does not believe in the endurance of the Yiddish language can, perhaps, be considered a Yiddish linguist, but such a person cannot be a Yiddish philologist. Linguistics deals with only the forms of the language, while philology deals with the cultural products of the language" (Borochov 1913, page 356 in this issue, n. 2). This "first amendment" to the Yiddish academic constitution would be applied beyond the scope of philology. From its inception, modern Yiddish scholarship with Borochovian "philological" (de facto, ideological) commitment would become part of all Jewish nation-building projects, whose linguistic platform was Yiddish. Borochov himself left a more significant corpus of writings devoted to economic and social rather than philological aspects of Jewish life. Such Marxists as Lestschinsky and Borochov were primarily interested in gauging the strength of the Jewish proletarian movement, because without a proletariat - the driving force of history (according to Marx) - Jews could not qualify for a significant role in the revolutionary transformation of the world.

Jewish socialists, most notably Labor Zionists and Bundists, strongly believed that Imperial Russia in its late period had a sufficient Jewish proletarian mass. They waved aside the theory of "non-proletarization" of Jewish workers, formulated in 1902 by Chaim Dov Hurwitz (1865-1927), the pioneer of economics journalism in Yiddish. Hurwitz argued that in the anti-Semitic environment of Russia, Jewish workers were unequal in the labor market. In particular, he claimed that they could be employed in handicrafts and home-industries, but had little chance of becoming factory workers, i.e. real proletarians. He based his theory on the model of the nineteenth-century German economist Wilhelm Roscher, who maintained that Jews could play a significant role only in pre-market economies. Although Hurwitz soon distanced himself from his thesis, it was taken up by Lestschinsky, who emerged as an ideologist and (in Borochov's words) "the most serious social economist" in the Zionist Socialist Workers' Party, which was established in 1904 by those Territorialists whose doctrine was based on a Marxist rationale (Borochov 1935, 10-11; Frankel 1984, 325; Hart 2000, 203, 215). For Zionist Socialists, “non-proletarization" (or "non-industrialization”) became one of the principal arguments for attempting to direct the emigration from Russia's Pale of Jewish Settlement to places where proletarization might eventually be achieved.

Lestschinsky was cut from a different cloth than Borochov, a scion of a wellassimilated urban family who learned Yiddish only by the end of the second decade of his short life. Lestschinsky was a shtetl boy, born and bred, through and through. His home shtetl of Horodyshche, then in Russia's Kiev province, is now a town in 
the Cherkasy region of Ukraine. The first twenty years of his life he spent in the environment of his pious Yiddish-speaking family, combining religious studies with helping his parents run their store. Ultimately, reading non-religious Hebrew texts radically changed his life. First, he began to read the Hebrew newspaper HaMelitz. Then someone, perhaps his enlightened friend Ber Slutsky (later a Soviet Yiddish scholar and writer), gave him Kalman Shulman's Hebrew translation of Eugene Sue's Les Mystères de Paris. His father caught him reading the book and immediately burned it. In 1956, when numerous articles marked Lestschinsky's eightieth birthday, one of the writers asked rhetorically: "Is there a playwright who can make this drama understandable to the contemporary generation?" (Berman 1956, 10; see also Manor 1961, 38).

In 1896 Lestschinsky fled his shtetl and settled in Odessa, a magnet for provincials eager to attend its secondary schools. He lived in poverty, barely surviving by giving Hebrew lessons and trying to prepare himself for external matriculation. In his autobiographical note written in 1911, he recalled that in Odessa, at age 20, he "for the first time realized that apart from the Talmud there was also another kind of scholarship." It took him three years to master the eight-year Russian secondary school (gymnasium) program, including mathematics, history, and three languages: Latin, German, and French. ${ }^{2}$ Meanwhile, he was introduced to the ideological discussions of that time. Although Jewish life in the city was dominated by the grain trade rather than by scholarship or culture, it also boasted a vocal group of Palestinophiles, particularly Ahad-Ha'am's followers (Zipperstein 1993, 68-72). After reading Ahad-Ha'am's 1895 book Al parashat derakhim (At the Crossroads) Lestschinsky became a Hebraist and an agitator for Ahad-Ha'amist cultural nationalism. Puah Rakovsky, a Zionist educator, remembered Lestschinsky as "a loyal Zionist who spoke only Hebrew" and claimed his readiness to commit suicide if Zionism could not be realized (Rakovsky 2002, 60).

In 1901 Lestschinsky went to Switzerland, where he studied social sciences and philosophy at the University of Bern. In the student circles he had access to socialist literature; six months later, when he returned to Russia, he briefly anchored himself in the emerging Labor Zionist current. He wrote, hectographically copied, and distributed letters in Hebrew, hailing the Zionist halutzim (pioneers) as the avantgarde of Jewish revolutionaries. Together with his brother Joseph (1884-1935), later a prominent Bundist in independent Poland, he established a school for modern Hebrew in their home shtetl of Horodyshche. In 1903 he was elected as a Warsaw delegate to the Sixth Zionist Congress (often called the "Uganda congress") in Basle, where he joined the nascent Territorialist movement (Meisel 1926, 610-611; Reisen 1930, 281-4; Rafalsky 1946, 383-7; Manor 1961, 42).

The same year saw the publication of his first statistical research article, "Statistics of a Town," which appeared in Ahad-Ha'am's brain-child, the Hebrew journal

${ }^{2}$ YIVO Archive. Papers of Jacob Lestschinsky, RG 339, Folder 125. 
Ha-Shiloach. Lestschinsky's study was one of the by-products of the census conducted in the Russian Empire in 1897. Jewish intellectuals were hugely disappointed with its returns, which revealed the predominantly "non-productive" occupation of Russian Jews. By that time, "productivization" already was an obsessive idea in Jewish intellectual circles. In St. Petersburg, the Society for the Promotion of Agriculture and Artisanship among Russian Jews (ORT) was formed as early as 1880. Productivization brought to life the Jewish Colonization Society (1891), whose founder, Baron de Hirsch, launched the remarkable colonization scheme in Argentina. Another baron de Rothschild - poured his millions into agricultural colonies in Palestine. The Jewish Colonization Society sponsored statistical studies of Russian Jews. More than one thousand people participated in collecting local data. Lestschinsky conducted a similar regional case study in Horodyshche that formed the basis for his 1903 article, which concluded that there were direct links between the social and class composition of the Jewish population and its economic structure (Zukerman 1937, 221-222; Friedman 1956, 406; Manor 1962, 101-2).

Productivization, most notably through proletarization, became one of the objectives of Jewish Marxists of various political hues. Arcadius Kahan, a historian of Jewish social and economic life, wrote about it:

We should ask the question: if the economic development of the country would have allowed the growth of the middle class (including merchants and liberal professions) and discrimination against the Jews would not have been a matter of governmental policy (let us say the Pale were abolished and access to all kinds of employment would have become a matter of merit), would there have been a need for proletarization or other employment shift of the Jews? The answer would probably be in the negative, unless one subscribes to the early Marxian prediction that the middle class was on the verge of disappearing and the development of society would leave only two classes, proletarians and capitalists. (Kahan 1986, 43-44)

The Zionist Socialist Workers' Party did subscribe to the "early Marxian prediction." Lestschinsky helped establish the embryo of the party and organize its first conference in Odessa in December 1904. He was elected to the party's Central Committee, but all fourteen participants of the conference were arrested, therefore a proper founding conference would be convened in Leipzig in 1906 (Meisel 1926; Rafalsky 1946, 3837; see also Patkin 1947, 222-28, 237-41). The change of Lestschinsky's linguistic preference, from Hebrew to Yiddish, reflected his ideological transformation.

\section{Theories and Utopias}

After "Statistics of a Town" Lestschinsky focused on insights about the economic and social conditions of various Jewish communities. In 1904 he published in Yitshok Leybush Peretz's Yiddish-language Yidishe bibliotek (Jewish Library) his research 
"Di yidn in London" (Jews in London); in 1907 it came out as a pamphlet, entitled Der yidisher arbeter in London (The Jewish Worker in London) (Lestschinsky 1907). The same year it appeared in Russian as Evreiskii rabochii $v$ Londone. In this study he for the first time came to a conclusion that he would repeat numerous times in his later publications: organized emigration could remedy urgent problems of Jewish life. He opined that, while previous waves of Jewish emigrants would usually find a better life in the pre- or early-capitalist countries, contemporary Jewish emigrants, who arrived chaotically from Eastern Europe, wound up at the very bottom of the American and western European societies. As a result, Jewish immigrants in London were ready to emigrate again. Thus, organized emigration was imperative not only for the overcrowded Pale, but also for the immigrant communities in the West.

In 1906 Lestschinsky participated in the Leipzig conference of the Zionist Socialist Workers' Party. However, when he started reading his programmatic paper, he had a brainstorm, realizing that his reasoning lacked logic. As a result, he interrupted his presentation and quit the gathering. He moved to Berlin where he lived a cloistered life for six months, writing his Marxist analysis of Jewish proletarians' life in Russia (Rafalsky 1946, 386-7; Manor 1961, 46).

In Der yidisher arbeter in Rusland (The Jewish Worker in Russia), published in 1906, ${ }^{3}$ Lestschinsky used available statistics as proof of his thesis that Jews had no chance of forming a significant factory proletariat in Russia and that therefore only territorial concentration of Jewish masses could correct the abnormality of East European Jews' class structure (Lestschinsky 1906; see also Mendelsohn 1970, 60; Jacobs 1992, 136). His belief that only the proletariat was able to mold human civilization into an egalitarian commonwealth of peaceful nations led him to frustration, when he could not find a significant mass of Jewish proletarians. Moreover, he could not see how Jewish factory workers could increase in number in the Russian Empire, where only minor, parochial Jewish entrepreneurs could tolerate the reputation of running a "Jewish business." Owners of enterprises with markets outside the Pale shunned such a reputation and, therefore, preferred to employ gentile workers. In general, Lestschinsky argued, the workers and the bourgeoisie had fundamentally different attitudes toward their country of residence, particularly when the development of capitalist forms of production entailed, on the one hand, increasing exploitation of laborers and, on the other hand, enrichment of the bourgeoisie. He diagnosed that, as a result, the Jewish proletariat felt a strengthening of Jewish nationalism with a growing sense of alienation from the homeland (most notably Russia), while the Jewish bourgeoisie were becoming increasingly more patriotic and more prone to assimilation.

This treatise became an ideological cornerstone of the Zionist Socialist Workers' Party (Manor 1961, 74-75). Lestschinsky participated in the party's 1910 conference in Vienna. By that time, following the defeat of the first Russian revolution (1905-7),

\footnotetext{
${ }^{3}$ It appeared the same year in Russian as Evreiskii rabochii v Rossii.
} 
the party had shrunk to a small circle of committed activists. Biding their time, many socialists concentrated their efforts in "organic work," that is social, cultural, academic, and educational areas (Gassenschmidt 1995, 70). In the academic year of 1907-8, Lestschinsky joined the faculty of the Jewish section at the Warsaw-based University for All. Established by socialist intellectuals, the university was the only institution of higher education in the Russian Empire completely open to all ethnic and religious segments of the population (Zimmerman 2004, 240). From 1908, Lestschinsky worked as a columnist for the Warsaw Yiddish daily Haynt (Today), writing about economic issues of Jewish life, and he contributed to the Russian and Hebrew press (Meisel 1926). He also continued his research on economic and demographic aspects of contemporary Jewish life. For instance, his 1910 German article analyzed the first results of the immigration to the United States organized by the Galveston Movement, which attempted (in vain) to disperse the fast-expanding population on the Eastern seaboard and prevent an anticipated wave of anti-Semitism (Lestschinsky 1910). A more comprehensive study came out as a Russian pamphlet (Lestschinsky 1912).

Shortly before the 1910 Vienna conference Lestschinsky was expelled from Russia and went to Zurich, where he would live and study until 1914. In the spring of 1911 he applied to Zurich University. Together with his application he submitted a letter written by the Vilna rabbi I. M. Rubinstein, who hailed Lestschinsky's knowledge of the Talmud and "other Jewish writings." Taking into account the submitted papers and Lestschinsky's publications in German, Yiddish, and Hebrew, the Dean of the Faculty of Law and State (Rechts- und Staatswissenschaft) allowed him to audit lectures at the university. ${ }^{4}$ Like many other students from Russia who audited lectures at West European universities, Lestschinsky never received a degree.

Judging by an article on psychology of Jewish immigrants written during his Zurich period, Lestschinsky did not see any comforting signs in the economic conditions of East European Jews who were arriving en masse to countries such as the United States. He was disappointed that the bulk of the immigrants tended to slog in small workshops and, instead of participating in various forms of class struggle, dreamed about opening their own workshops one day. Lestschinsky contended that Jewish immigrants could not become productive as proletarians because the majority of them were deficient in the required skills for qualified jobs and had no physical aptitude for hard manual work. Hence their concentration in semi-artisan workshops of the garment industry (Lestchinsky 1913, 75-80).

In 1913-14, Lestschinsky headed the Bureau for Jewish Statistics and Economics, based at a Jewish library in Vilna. ${ }^{5}$ From 1914 he worked in Warsaw for the local bureau of ORT. As an expert in its Relief-Through-Work Department, which was

\footnotetext{
${ }^{4}$ YIVO Archive. Papers of Jacob Lestschinsky, RG 339, Folder 125.

${ }^{5}$ A. Z. Brezin, one of the bureau's volunteers, later published in Israel Atid hamizrah, the short-lived weekly for commerce, industry, building, and agriculture (see Brezin letter to Lestschinsky dated 13 Nov. 1928. YIVO Archive. Papers of Jacob Lestschinsky, RG 339, Folder 7).
} 
formed to find gainful occupation for Jewish refugees of World War I, he visited such towns as Vilna, Minsk, Zhitomir, Uman, Kovno, Fastov, and Dvinsk (Shapiro 1980, $75,81)$. Forced mass migration from the war-ridden Pale worried him, particularly as a factor that could detach the Jewish entrepreneur from the Jewish worker and, as a result, denationalize and emasculate Jewish economy (see Freitig 2004, 64-5).

Lestschinsky participated in the Petersburg journal Vestnik evreiskoi obshchiny (Herald of the Jewish Community, 1913-1914), whose program derived from the historian Simon Dubnov's ideas of building Jewish autonomy on the basis of modernized Jewish community (kehile) (Fishman 2005, 78). In the late 1910s the Dubnovian Folkspartey attracted a number of activists who previously were leading Zionist Socialists (Balberyszki 1954, 238). Yet when Lestschinsky immersed in politics after the 1917 revolution in Russia, he joined the United Jewish Socialist Labor Party (or Fareynikte), a new political amalgam, in which former Zionist Socialists played a central role. The new party became particularly active in Ukraine, whose parliament promised and, in January 1918, declared national-personal autonomy to Jews. Emigration and territorial projects disappeared temporarily from Lestschinsky's agenda.

In 1918, he published a pamphlet, Jewish Autonomy Once and Today, analyzing the nature of the Jewish community life in pre-partition Poland (Lestschinsky 1918a). Echoing Dubnov's narrative, he contended that autonomy had been formed by the Jews primarily as a direct result of the history of their peculiar, segregated life in Eastern Europe. In any case, autonomy had not been simply bestowed by the Polish rulers. Rather the authorities used the already-existing autonomous structures to serve additional functions. In nineteenth-century Russia, the old Jewish autonomy was ruined and Jewish society was significantly modified due to the following three processes: (1) decline of the number of middlemen and increase in the number of workers; (2) class differentiation; (3) urban concentration. These processes created an environment for a new Jewish autonomy, whose main advocates and benefactors would be (predictably for a Marxist thinker) workers. The same year, Lestschinsky brought out another pamphlet, entitled Our National Demands, presenting his vision of post-imperial Russia's federal composition (Lestschinsky 1918b). His blueprint pictures Jewish life in the framework of "personal" rather than territorial autonomy. In Lestschinsky's utopia, citizens are entitled to become members of the Jewish (and for that matter any other national) communal structure, which has a representation in all decisionmaking and executive institutions of the state. The community is secular (albeit it also takes care of its religious minority) and is governed by a democratically elected national parliament. It controls predominantly the cultural domain of national life the educational network, publishing, libraries, theaters, and museums - which secures the preservation and further development of the nation.

In the late 1910s and early 1920s, the idea of Jewish autonomy was popular among those theoreticians who believed that, in the post-World War I political climate, the Jewish community could transcend its traditional religious and social functions and reinvent itself as an integral - but at the same time autonomous - component of the 
corresponding country's economic and cultural organism (see, in particular, Khashin 1921, 12-13). Together with many other Jewish activists, Lestschinsky saw the post1917 Ukrainian environment as a golden opportunity to build a viable organizational framework for Jewish nationalism to flourish. He was one of the leading figures in the Kultur-lige (Culture League), a supra-partisan network of Yiddish cultural organizations with a Kiev-based coordination center. During the year 1919 the Kultur-lige reached the climax in its activities, but in 1920 the Bolsheviks took the league under their control and used its components for developing their system of Jewish educational and cultural institutions (for Kultur-lige, see in particular Kazovsky 2003).

During the ensuing 45 years of his life outside Russia, Lestschinsky would work jointly with many organizations, but - to the best of my knowledge - he would never become a card-carrying member of any party. His last political affiliation was with the short-lived Fareynikte-Bund hybrid. In 1921, his brother Joseph joined the Polish Bund, but Jacob remained an unaffiliated Jewish Marxist. Known to his friends as a romantic, whose attitudes were not set in stone and who could be carried away by new ideas, he could not be a disciplined member of a party. Yet there were shibboleths: he never deviated from the main objective of his life, which was to find most reliable models for Jewish national survival.

\section{The Forverts Man in Berlin}

Following the defeat of all non-Soviet political and military groupings in Russia, Berlin became a stronghold of Jewish intellectual immigration. Many of the activists who fled from Russia and settled in Berlin believed in a territorial solution of the Jewish problem. Three decades later, Lestschinsky wrote that during the twelve years of his life in Berlin his circle of intellectuals "gave thought to five or six serious territorial projects and to three or four not serious ones" (Lestschinsky 1951a, 4). In the meantime, he continued to measure the composition and distribution of the Jewish population.

In the early 1920s, Germany became a leading producer of Yiddish books. For Lestschinsky, it was a chance to realize some of his projects. As early as the summer of 1919 he had a ready manuscript of the book Dos yidishe folk in tsifern (The Jewish People in Figures) and by the end of the year it was sent to typesetters. However, in the turmoil of the civil war in Ukraine it did not come out until 1922, under the imprint of the Berlin Klal-Farlag (Public publishing house), formed as a continuation of the Kiev-based Yidish folks-farlag (Yiddish people's publishing house). In the preface, Lestschinsky explained that his work targeted a few kinds of readers, combining functions of a textbook, handbook, and a book for the general public.

Lestschinsky belonged to the school of thought that found the existing Jewish culture ill-fitted for use in modern nation-building. He argued that while proletariats usually inherited cultural treasures produced by other classes of their nation, the Jewish proletariat inherited only one more or less developed cultural branch - belles-letters. At 
the same time, he was happy that Yiddish literature had little to do with the bourgeoisie and that the bulk of its characters were earthy people (Lestschinsky 1918a, 44-7). In October 1921, he finished writing his only significant literary study: Dos yidishe ekonomishe lebn in der yidisher literatur (The Jewish Economic Life in Yiddish Literature). Apparently, the pamphlet was published at least twice, first in Minsk and then in Leipzig. The 1922 Leipzig edition came out as an offshore publication of the Jewish Section at the Soviet Commissariat (Ministry) for People's Education. Lestschinsky's pioneering work on the reflection of economic life in Yiddish literature was based on his 1920 lectures, which (as the imprint informs us) he read in Minsk to students of Yiddish teachers-training courses, presumably at the time of his short-lived membership in the Soviet-leaning Fareynikte-Bund coalition. ${ }^{6}$ Appropriately, the pamphlet followed the rules of the recently introduced spelling code, which naturalized all Hebrew and Aramaic forms used in Yiddish. In his analysis, Lestschinsky divided Yiddish writers into three partly overlapping cohorts, according to the character of Jewish economic and social life they portrayed in their writings: (1) the old economy of merchandising was presented by such early writers as Mendele Moikher Sforim and Ayzik Meir Dyk; (2) Yitshok Leybush Peretz, Sholem Aleichem, and a few more writers' works showed the birth throes of contemporary Jewish life; (3) in the writings of such authors as David Bergelson, Sholem Asch, and Abraham Reisen one could already find the modern class stratification of the East European Jewish religious community and its transformation into a modern nation (Krutikov 2001, 14-15).

By the time Lestschinsky arrived in Berlin, he was an experienced newspaperman. Apart from writing numerous articles, he was one of the editors of the Kiev Naye tsayt (New Time, 1917-1919). Readers of his early Yiddish works and his texts published in 1918 and later can see the radical improvement of his style. To all appearances, he nursed an idea of publishing a Yiddish newspaper in Berlin and even began recruiting people for his (ultimately aborted) project; in September 1921, the social worker and journalist Vladimir Grossman suggested himself as a co-editor. ${ }^{7}$ Ultimately, however, the masscirculating New York daily Forverts (Forward) appointed Lestschinsky, in December 1921, to head its Berlin-based bureau. As a result, he became part of the small group of fortunate Berlin literati, who had stable contracts with American newspapers and could enjoy a middle-class standard of life (Rubin 1930, 262-3). His Berlin circle was very wide, including (predominantly) East European and (to a lesser extent) German Jewish intellectuals. Bergelson, a central Yiddish literary figure in Kiev and, from 1921 to 1933, in Berlin, was Lestschinsky's close friend. Friendship linked Lestschinsky also with Simon Dubnov, whom he highly respected, though he could not agree with the historian's anti-Marxism (Lestschinsky 1931b, 123-9). ${ }^{8}$

\footnotetext{
${ }^{6}$ He later recalled "large halls packed with students" attending his Minsk lectures (see Lestschinsky 1924a, 11).

7 YIVO Archive. Papers of Jacob Lestschinsky, RG 339, Folder 10.

${ }^{8}$ Lestschinsky considered Dubnov's plea for national-cultural autonomy, formulated in his 1897 "Letters on Old and New Jewry," one of the major events in modern Jewish history (see also Dubnov-Erlich 1991, 207).
} 
Apart from reporting and analyzing events in Germany, the bureau regularly provided material about life in the Soviet Union. Although Lestschinsky and other journalists had links with the Soviet embassy, their Soviet-related articles were often reprocessed from the Soviet Russian and Yiddish press. In his analysis of incoming information, Lestschinsky warned of a weakening of the Jewish proletariat, whose cream had changed its social position: many former proletarians had emerged as Soviet apparatchiks or used the opportunities of the New Economic Policy to become businessmen and self-employed artisans (Lestschinsky 1924a, 12; Lestschinsky 1924b, 9-11). In 1925 he published in Berlin, under his own imprint, the pamphlet Der emes vegn di yidn in Rusland (The Truth about the Jews in Russia) (Lestschinsky 1925). Under this sensational title he quoted numerous pieces of Soviet journalism showing the decline of the shtetl. At the same time, he was happy to read articles exemplifying the two bright spots on the dark sky of Russian-Jewish life: first, proletarization of people who had found jobs as factory workers and achieved a relatively high standard of living; second, productivization of families who had moved to rural areas and worked the land. However, the flow of people moving to factories and agricultural colonies was but a trickle compared to the masses of destitute Jews dwelling in Soviet towns. Lestschinsky believed that only incipient reform and, generally, an economic rebirth of Russia could eventually improve their living conditions.

To a marked degree, his attitude reflected the position of such organizations as ORT, which in August 1921, during its first postwar conference in Berlin, had transformed itself from the hitherto Russian charity into the World ORT Union. Bergelson, too, became involved in ORT activities. In 1924, he went on a mission on behalf of ORT, visiting Rumania to meet local Jewish farmers there. From Iassi, he wrote to Leshschinsky, on 18 November 1924, arguing that ORT might become "a national movement, swallowing and digesting in its healthy stomach all our 'redemption'preaching currents." " However, Lestschinsky always had reservations about the priority of agricultural colonization, which - from a Marxist point of view - could be seen as a deviation from the socialist and industrial future. Granted, he found some sides of the Soviet Jewish colonization appealing, such as its state-sponsored character, its approximation to a grassroots movement, and its new concentration of the Jewish population (Lestschinsky 1926, 4).

Time and again he wrote about paradoxes of Soviet Jewish life. On the one hand, revolution brought a lot of hardship. Yet he also did not forget that while the Provisional government had decreed civic equality for Russia's Jews, it was the Bolsheviks who had secured the Jews' national equality (see, e.g., Lestschinsky 1932a, 48). His weighty 1941 volume devoted to Soviet Jewry would praise some components of the Soviet "laboratory for all [available] methods of solving the Jewish problem" and particularly the results of Soviet Jewish colonization projects in the Crimea and Ukraine. He laid the blame on the Jews rather than the government for "taking the

${ }^{9}$ YIVO Archive. Papers of Jacob Lestschinsky, RG 339, Folder 7. 
line of least resistance ..., which in the Soviet Union meant to become white collars and intellectuals." He admitted that it was the best choice for Jewish individuals, but their personal success in Soviet society did not contribute to the general Jewish course of preserving and developing the Jewish nation. Moreover, by bettering themselves and occupying numerous visible positions in Soviet society Jews made a nuisance of themselves, provoking more envy and hatred among the gentiles (Lestschinsky 1941; see, in particular, 10, 168-9).

In the 1920s, Zionism also appeared to Lestschinsky as a shaky and pernicious project. In 1926 he argued:

Unfortunately, it is now evident that Eretz Israel [i.e. Palestine] will not turn into a land of immigration for many Jews. It transpires that it is easier to move worlds than to build them. Every fantasy is harmful. ... Our struggle must be against illusions and fantasies, against vain aspirations and futile plans of being bigger, stronger, deeper, and broader. In Jewish life too little is invested in practical daily labor for the interests of the masses, so we cannot afford the luxury of supporting the Zionist wagon, in which we do not believe. (Goldstein 1998, 204-205)

He was against concentrating Jewish political energy on only one Zionist or nonZionist (Communist, Territorialist, etc.) project and called for Jews in the Diaspora to liberate themselves from the atmosphere of Exile and build their future in the countries where they lived. In the wake of the anti-Jewish riots of Arabs in August 1929, spurred, as Lestschinsky claimed, also by provocative actions of Jewish extremists (Lestschinsky 1929, 6-9), he saw Palestine as simply another dangerous place in the Jewish Diaspora. He compared Zionists with the followers of the seventeenth-century "false messiah" Shabbatai Zvi. Being ready to accept the Zionists' commitment to building Jewish life in Israel, Lestschinsky condemned those radicals who undermined Jewish life in the Diaspora:

... we see how Zionism keeps ruining the Jewish soul, how it deprives the Jewish masses of their feelings of citizenship, of having birthrights to the country of their residence, and of equality with the surrounding population. We see how Zionism does not allow the Jewish masses to concentrate their thoughts on local economic, political, and cultural issues and problems. Instead, it exhilarates them with illusions and promises, which can intoxicate but cannot produce results. (Lestschinsky 1930)

\section{Yiddish Scientific Institute}

In 1923-25, Lestschinsky was the front person among the three editors of the pioneer Yiddish academic periodical Bleter far demografye, statistik un ekonomik (Pages for Demography, Statistics and Economics). The two other editors were Prof. Boris Brutzkus and Dr. Jacob Segall (the latter was the editor of the German journal Zeitschrift für Demographie und Statistik der Juden, and both Leshschinsky and Brutzkus were its 
contributors). In his programmatic article on the aims of Jewish statistics, Lestschinsky contended that, due to their demographic, cultural, and behavioral peculiarities, Jews had to be categorized and analyzed as a separate group. He emphasized that racial features could not explain the existing differences between Jews and non-Jews, especially given the significant disparity between various Jewish groups. Furthermore, differences between a Jewish group and a non-Jewish group were less significant if both groups lived in an urban center, where dissimilarities between Jewish and non-Jewish intellectuals and bourgeoisie almost came to naught (Lestschinsky 1924c, 1).

In August 1925, Lestschinsky took part in a meeting that laid the foundation for the creation of the Yiddish Scientific Institute, YIVO (for the establishment of YIVO, see Kuznitz 2000). The idea of founding a Yiddish academic center belonged to Nokhum Shtif, another Yiddishist activist-cum-scholar, who also once espoused the theory of "non-proletarization." During the same Berlin meeting, it was decided that two sections of the institute be created in Berlin: the Historical Section and the SocialEconomic (later called Economic-Statistical) Section. Lestschinsky was chosen as the head of the latter, and the Bleter far demografye, statistik un ekonomik became the section's organ. In fact, the Bleter had to be phased out because there were no sponsors ready to support a Yiddish-language journal devoted to social, demographic, and economic issues. ${ }^{10}$ Only three years later, in 1928, Lestschinsky edited the first volume of the Shriftn far ekonomik un statistik (Journal for Economics and Statistics), which came out in Berlin as an organ of YIVO's Economic-Statistical Section. The second volume of the Shriftn came out only four years later, in Vilna, under the title of Ekonomishe shriftn (Journal of Economics).

Although Vilna was initially seen as the place for only one of YIVO's sections, the Philological one, its head, the linguist Max Weinreich, turned out to be the most efficient organizer among the fathers of the Yiddish institute. In addition, with its devoted Yiddishist intellectuals and communal leaders, Vilna created a much better environment than Berlin or Warsaw for such an institution. As a result, the institute's headquarters emerged in Vilna. In 1930, Lestschinsky lamented the lack of money and suggested that his sector be closed or moved to Vilna. In his letter of 7 October 1930, Weinreich asked him to keep the sector afloat, at least pro forma, even without money. ${ }^{11}$ Earlier in the year Lestschinsky visited Vilna and found it in an awful economic decline. According to him, Vilna was "a dead town" as an economic organism. At the same time, the cultural and academic life in the town was on the rise and the building of YIVO was almost ready, because (according to Lestschinsky) many people found solace in scholarship and the arts (Lestschinsky 1930a, 3; see also Lestschinsky 1931a, 21-33).

Lestschinsky's 1930 Vilna sojourn was part of his trip to Poland, which he documented in a number of newspaper and journal articles. He singled out three calamitous manifestations of the critical state of Jewish life in Poland: the epidemic of

\footnotetext{
${ }^{10}$ See Lestschinsky's June 1926 correspondence with Abraham Coralnik. YIVO Archive. Papers of Jacob Lestschinsky, RG 339, Folder 63.

${ }^{11}$ YIVO Archive. Papers of Jacob Lestschinsky, RG 339, Folder 23.
} 
suicides; abandoned children; and fainting from hunger in public places (Lestschinsky 1948, 21). In the Berlin journal of ORT, edited by Ben-Adir (Abraham Rozin), a veteran Territorialist and a member of the Economic-Statistical Section, Lestschinsky wrote about the appalling physical, spiritual, and moral conditions of the "social junk" that comprised about one-eighth of Polish Jewry.

\begin{abstract}
All these widows, orphans, old people, homeless artisans, workers who have no hope of finding a job, invalids [of the war], physical, mental, and moral cripples, old maids, half-idiotic young men, people uprooted by the war, simply impoverished people and runaways from villages, victims of violent or economic anti-Semitism - these whole social riff-raff floods from the town-center to the gutter, whose name is "market." Not only it is a heavy burden for the whole Jewish community, but it is also a dangerous contagious nucleus, that attracts less healthy elements, pollutes the atmosphere in which the young generation grows, and contaminates the surrounding social elements with the poison of market and venom of fair. (Lestschinsky 1930-1931) ${ }^{12}$
\end{abstract}

Note the tone of disparagement, amounting to contempt for the "non-productive" Polish Jews. Poland epitomized the pre- and early-capitalist forms of Jewish life that socialists such as Lestschinsky deeply hated. Little doubt that Lestschinsky's attitude to Poland also had much to do with his non-Polish origin. Ukrainian and Lithuanian Jewish intellectuals often regarded the Polish Jews as a particularly underdeveloped segment of the East European Jewish population. Still, a few years later he would be forced to live in Poland. On 11 March 1933, the German police arrested Lestschinsky for sending correspondence to Forverts. It was arguably the first arrest conducted by the Nazis in the Berlin-based foreign journalist colony. Under pressure from the American State Department, Lestschinsky was released after spending four days in prison, but was given orders to leave Germany in two weeks' time (New York Times 1933a; New York Times 1933b; Lestschinsky 1933a). Warsaw, the most significant Jewish center in Europe, was the only place in Europe where he, with some command of Polish, could be useful as a Forverts representative.

\title{
Back to the Ghetto
}

By the end of his Berlin stint, Lestschinsky apparently lost faith in all formulas of successful multiethnic coexistence and advocated a kind of neo-ghettoization. In his article "Ghetto and Migration in Jewish Life," he wrote:

Ghetto and migration are the two pillars that have been sustaining Jewish national life in the Diaspora. The ghetto, which had geographically and socially delineated us and separated us from the surrounding population, had also isolated us behaviorally and

\footnotetext{
${ }^{12} \mathrm{He}$ published this article in four issues of the journal and in 1931, this work came out in Berlin in book form.
} 
culturally from non-Jewish life, creating as a result the basis for our own historically developed forms of communal life. ...

The migration interrupted again and again the unavoidable processes of assimilation. Thanks to the migration, assimilation never damaged the roots of Jewish national life. Rather, assimilation was kept in such a minimal proportion that it could not endanger the cultural structures and forms of communal life, which had been historically accumulated and later preserved in the ghetto.

However, capitalism ruined the ghetto, implemented new class structure in Jewish society, and created much more favorable conditions for both assimilation and national development. It also produced the Jewish homo economicus, who was rational and little interested in spiritual values. For all that, capitalism failed to bring these processes to any final results. It did not finish assimilation nor did it create a healthy economic and cultural basis for concentration of Jewish masses. (Lestschinsky 1933b)

In 1942, in an obituary devoted to Ben-Adir, Lestschinsky would explain the reasons for the deceased's and, no doubt, at least partly his own about-face from optimism to pessimism regarding Diaspora life. He wrote: "only deaf and spiritually poor people can in our time, not only in the Hitler years but, even earlier, in the Pilsudsky years, remain Diaspora optimists." He listed the dispiriting factors: sadness of Jewish life in Poland; failure of Jewish autonomy in Lithuania, Latvia, and - earlier - in Ukraine; anti-Semitism in the young East European countries (Lestschinsky 1942). In any case, in the second half of the 1930s, Lestschinsky apparently would not have written the editorial, which he penned in March 1932 for the volume of Ekonomishe shriftn, where he stated his attitude to the Jews-related research, alluding to the idea of coexistence of Jewish and non-Jewish citizens:

... the economic destiny of each Jewish social group is ... much more dependent upon the destiny of the whole surrounding other-national environment than upon the destiny of other Jewish social groups. From the economic point of view, Jewish social groups and classes, let alone individuals, gravitate more to the corresponding social groups and classes of the non-Jewish environment than to the remaining sectors of the Jewish nation.

Therefore we maintain that scholars do not have any, even tenuous grounds, to speak about Jewish economy. (Lestschinsky 1932b)

By 1937 he changed his position and already saw (or wanted to see) signs of Jewish autonomous economy. Moreover, he suggested that the Polish Jewish community turn inward, introducing autarky, or closed economy, as the most powerful antidote to anti-Semitism. Social and professional re-stratification (ibershikhtung) was - according to Lestschinsky - the key to peaceful coexistence with the co-territorial population. Autarky meant a society-wide shift of Jews' professional aspirations: expansion to menial 
and low-wage occupations, development of agricultural production in every shtetl and, generally, achievement of economic independence from their gentile neighbors. He hailed halutzim for playing a revolutionary role in the Jewish labor movement and advised that Polish Jewish teenagers be encouraged to spend their summer vacation working for Jewish farmers and becoming familiar with agricultural work (Lestschinsky 1938).

Lestschinsky's suggestion that Jews develop a closed, self-sufficient Jewish economy was his reaction to the contemporaneous crisis in European Jewish communities in such countries as Poland, Rumania, and Lithuania, where nationalist regimes had introduced autarky and forced out Jewish entrepreneurs and workers. He argued that Jews continued to live mit laytn glaykh (no worse than anyone else) only in those countries, such as the United States, Great Britain, France, and Canada, that preserved essential forms of nineteenth-century capitalist liberalism. Even Soviet Russia appeared to Lestschinsky to be a better place than Poland. He distinguished three reasons why Poland did not follow the Russian politics toward Jews. First, Poland did not have territories for Jewish colonization and could not even consider such projects as Birobidzhan. ${ }^{13}$ Second, while tens of thousands of Jews in Russia had replaced the pre-revolutionary white-collar cadre, independent Poland did not have such a dearth of educated people. Third, thanks to the rapid industrialization in Russia jobs were created also for Jews, whereas chronic unemployment was characteristic of the Polish economy. Significantly, Russia sought to transform its Jewish population rather than to push it out. As for Poland, only emigration might partly solve the problem (Lestschinsky 1936c; Lestschinsky 1937-1938). ${ }^{14}$

According to Lestschinsky's calculations, emigration of at least 50,000 or even 60,000 Jews a year was needed for Poland like "a gulp of air," because Jewish overpopulation was one of the main reasons for Polish anti-Semitism (Lestschinsky 1936c, 10; Lestschinsky 1951b, 212-213). Because the gates to the United States were closed for mass immigration, he appealed to Polish Jewry not to be afraid to move to other countries, notably countries in South America. He maintained that in Jewish history migration always "played a positive, constructive role" (Lestschinsky 1936a, 3, 9). In the mid-1930s, many people believed that emigration could remedy the Jewish problem in Europe. Neo-Territorialism took organizational form in 1935, when the Frayland (freeland) League for Jewish Territorial colonization was formed during a conference in London. The popular German writer Alfred Döblin, Lestschinsky's Berlin acquaintance, took part in the London conference of the league, joined its World Committee, and edited the only German issue of the Yiddish journal Frayland (Steinberg 1953, 118-19; Zeller 1978, 36, 38). Among the neo-Territorialists'

\footnotetext{
${ }^{13}$ For the history of the Jewish autonomous territory in the far eastern part of the Soviet Union (now in Russia) see, e.g., Weinberg 1998.

${ }^{14}$ Jewish intellectuals traveling to Poland and Russia unanimously reported the superiority of Soviet Jewish life to the poverty and persecution they witnessed in Poland (see, e.g., Soyer 2000, 131).
} 
sympathizers was also Stefan Zweig, who believed that Jewish emigration "would relieve Europe not only of its surplus people, but also of its surplus enmities" (Zweig 1936, xi).

In May 1937, the first issue of Di yidishe ekonomik (Jewish Economics), a new organ of the YIVO's Economic-Statistical Sector, came out in Warsaw. Launched as a monthly, it soon became a bi-monthly. Lestschinsky, who was again the editor, explained in an article-manifesto that he saw the journal as "a purely scientific, objective forum for a widest range of issues of Jewish social life." At the same time, he promised that the journal would have its feet planted firmly on the ground, providing material for practical solutions to problems of contemporary Jewish life. Most importantly, it was urgent to find a way out from the situations in which Jews were fully dependent upon the vicissitudes of the fate of other nations. Echoing his early works, he mourned the end of the liberal epoch when people and capital could move freely from one country to another, which allowed Jews to form populous communities. In the 1930s, however, "[t]he amplitudes of ups and downs [in Jewish life] reached the level when we, sometimes, could find ourselves in the position of outcasts and, sometimes, could be promised to get a separate country for creating there a national statehood" (Lestschinsky 1937a, I).

In the second half of the 1930s, Lestschinsky began to gravitate to the Labor Zionist camp, which he had left in 1903. Around the same time, his relations with the Bund became very sour (see Lestschinsky 1935). He believed that its politics grew increasingly irreconcilable with Jewish national interests. Moreover, he argued that the whole Jewish revolutionary movement was in crisis. In the Soviet Union it had simply perished, while in other countries it had lost its radicalism. Against this background, Palestine remained the only place where it existed. One might reject the excesses of Zionism, such as its linguistic monism and, generally, ignoring the interests of the diaspora population. "Yet how can one vilify a movement that is from start to finish a freedom movement, which is imbued with social and national messianic ideals?" (Lestschinsky 1937b, 6). To all appearances, Lestschinsky's ideological transformation developed under the influence of similar changes in the political line of the Forverts, though initially, in the second half of the 1920s, he belonged to the anti-Zionist wing of the newspaper's contributors (Cahan 1930, 7; Rogoff 1940, 3-10; Rogoff 1954, 92-99; Osherovitsh 1957, 8; Goldstein 1998, 198-205).

\section{A Lapsed Yiddishist}

The Forverts editors preferred to have Lestschinsky in Europe and a couple of times even vetoed other American organizations' attempts to invite him as a lecturer. ${ }^{15}$ Yet

\footnotetext{
${ }^{15}$ See YIVO Archive. Papers of Jacob Lestschinsky, RG 339, Folder 77, in particular the letter of 15 September 1931 from the Educational Department of the Workmen Circle.
} 
in 1937, following his articles that exposed the pogrom atmosphere in Poland, the Polish government did not allow him, his wife Leah (sister of the Yiddish publicist and essayist Abraham Coralnik), and his daughter Tanya to return from their vacation in Czechoslovakia. In November 1938, after sojourns in Switzerland and France, the Lestschinskys, with the help of the Forverts, eventually arrived in New York. Dubnov, who moved in 1933 from Berlin to Riga (where he would be murdered in December 1941), envied his friend's "little nest in a New York skyscraper." 16 In the event, the 62year-old scholar-cum-journalist could not rest on his laurels. The newspaper, whose interests he represented for almost two decades, did not provide him with a salaried job. Therefore he had to earn living from lecturing, writing for various periodicals (including the Forverts, whose contributor he remained until 1956), and publishing books (Greyson 1966,1). Characteristically, by that time people already deemed him a sympathizer of Zionism. In one of Cahan's letters explaining why the Forverts could not employ Lestschinsky, the editor wrote (on 11 June 1938): "Here you have enough friends and if someone has a chance to establish himself here, it's such a person as you. Many parts of our and the Zionist movements require your participation."17

Lestschinsky's first impression of America was very favorable, even rapturous. However, soon he began to see the abyss that had opened wide between the first and the second generation of Jewish immigrants. He called it the "abyss between the present and the future." Seeing how little in common the young generation had with their parents, he began to understand why so many people were attracted to moving back to the "religious ghetto." He realized that processes of "denationalization" rather than assimilation were going on in such cities as New York. In other words, Jews were losing their national traits, but nevertheless they remained visible and their presence stuck in the gentile's throat like a bone. Therefore one day it would be tempting to get rid of it (Lestschinsky 1939, 8-9). No doubt, he applied the European, most notably the German Jewish experience to America.

In 1944, he participated in the YIVO project of collecting and analyzing opinions about the November 1943 instruction to exclude registration of Jewishness in recording the origins of entrants, issued by Earl G. Harrison, then Commissioner of the United States' Immigration and Naturalization Service. No doubt, this was an effort by the administration to make Jewish immigration "less visible" and to silence those who argued that the country was overrun with Jews (Goldberg, Lest[s]chinsky, and Weinreich 1945). However, people like Lestschinsky were angered at this decision, because their model of Diaspora life was based on the visibility and the vibrancy of Jewish communities.

The YIVO headquarters were now in New York and its director Max Weinreich was there too, but to Lestschinsky it was, to all appearances, a vestigial body. In January 1944 he sent a sharp letter to the Executive Bureau of YIVO expressing his unhappiness

\footnotetext{
${ }^{16}$ Dubnov's letter of 4 May 1939, published in Estraikh 2006, 17.

${ }^{17}$ YIVO Archive. Papers of Jacob Lestschinsky, RG 339, Folder 16.
} 
with the inundation of philological projects in the program of the institute. In April 1945 he decided to dissociate himself from YIVO, arguing that the main objective had to be preservation of the vanishing East European Jewish culture. ${ }^{18}$ Yet he remained a YIVO employee till 1950 and later also participated in its activities (Manor 1961, 54). In the meantime, he had found a new academic niche for himself - the Institute of Jewish Affairs, established in 1941 by the World Jewish Congress. Compilation and collation of factual material was one of the main objectives of the new institute (Institute of Jewish Affairs 1942).

In 1944, when the Red Army and the Allies were liberating Europe, Lestschinsky published a book devoted to methods of researching the Holocaust (Lestschinsky 1944). On 8 January 1945, the New York Times published a short article entitled "6,000,000 Jews Dead." The figure was estimated "by Jacob Lestschinsky, exiled economist and newspaper man, in an address at the nineteenth annual conference of the Yiddish Scientific Institute" (New York Times 1945, 17). In 1948, Lestschinsky published the results of his calculations of the Jewish population losses during the whole Holocaust period, which gave a figure very close to his May 1945 estimate: 6,093,000 (Lestschinsky 1948, 60). Gregory (Gszegorz) Frumkin, the statistician of the United Nations, had "the satisfaction to ascertain from a study of the material and from personal discussions, that the computations made for the American Jewish Congress were those of a highly competent and scrupulous scholar, J. Lest[s]chinsky." Still, Frumkin did not endorse the six-million figure, arguing that "information relating to the number of Jewish victims of racial persecution . . . is somewhat scarce" and that the real figure might be higher (Frumkin 1951, 11). ${ }^{19}$ In any case, outside the narrow circle of specialists, this measurement of the catastrophe almost immediately became detached from Lestschinsky's name.

In the meantime, Zionism increasingly appealed to Lestschinsky, particularly after the establishment of the State of Israel (Zuckerman 1956, 13-14). In 1947 he visited Jerusalem as a participant of the First World Congress of Jewish Studies. During the last two decades of his life Israel occupied the central place in his post-Holocaust models of Jewish life, shaping to reality his nation-building dreams. He welcomed aliyah (immigration to Israel) as the most successful form of organized and purposive Jewish migration. While all other ("elemental" in his terminology) migrations did not "eliminate the breach of the Jewish community of fate and the estrangement resulting from the language and cultural disruption," aliyah - he argued - aimed at the "liquidation of those conditions which cause[d] this breach and estrangement of the children of one and the same people" (Lestschinsky 1952, 12-13). In other words, he saw in Israel a direct continuation of the Diaspora Jewish civilization, whereas Diaspora meant, in his assessment of that time, anomaly in Jewish life, in particular because it was

\footnotetext{
18 YIVO Archive. Papers of Jacob Lestschinsky, RG 339, Folder 86.

${ }^{19}$ According to Sergio Della Pergola, the Jewish demographic authority, the overall number of Jewish victims "may fall in the range between 5.6 and 5.9 million" (Della Pergola 1996, 36).
} 
full with nation-destroying challenges: "Maximum freedom - minimum Jewishness! Maximum friendship of the alien surrounding - minimum cohesion among the own, Diasporic groups!" (Lestschinsky 1955, v). Zionism, however, was "the chief factor in the halting of the internal tendency toward assimilation and in providing the spiritual strength and courage to resist the external obstacles and to return with pride to the Jewish sources and origins" (Lestschinsky 1948, 107-8). He described his and other projects of Diaspora Jewish life as outdated ideologies, based on "the almost childlike faith in the steady advance of human progress and the impending triumph of Democracy throughout the world" (Lestschinsky 1963, 89).

Although Yiddish remained the principal language of his writing and communication, he became little interested in its maintenance in the Diaspora, because his new, Israel-centered model of Jewish life favored Hebrew. At the same time, he regarded language assimilation as a crucial consolidating factor for Diaspora communities and justified the Zionists' interest in accelerating such processes of assimilation. It was a pragmatic approach, because it was easier to deal with linguistically and culturally uniform communities (Lestschinsky 1955, 291). In his post-Holocaust vision, the Diaspora had to build numerous umbilical links with Israel:

... most importantly, aliyah. Physical aliyah which automatically develops into spiritual and cultural aliyah. Cultural aliyah through the Hebrew language and culture. Temporary aliyah - to send children to study at educational institutions in Israel. And even pure fundraising and political and economic support of Israel play a great nation role in keeping the Diasporic groups close to Israel. (Ibid., 427)

In 1955 he wrote to the historian Mark Wischnitzer, a one-time member of his Berlin circle of friends and colleagues:

We, and especially my wife, are so keen to have at least a brief look at Israel. I read a lot about the dangerous situation on the [Israeli] borders, but it does not make any impression on me. But when I read about a new novel, about a Hebrew book devoted to logic, about a Hebrew book on the history of philosophy, about a new poet, about a Yiddish poet who had already imbibed "the air of the Land of Israel," my heart virtually jumps, so happy I am. ${ }^{20}$

In February 1959, after spending a few years in Miami Beach, he emigrated to Israel, where some of his books appeared in Hebrew translations. Symbolically, the street in Tel Aviv where he lived was named after his old friend, Simon Dubnov. ${ }^{21}$ When he died, his funeral in Jerusalem was attended by Golda Meir and other Israeli dignitaries (Anonymous 1966, 1, 13).

${ }^{20}$ YIVO Archive. Papers of Mark Wischnitzer. RG 767, Folder “Letters, 1922-55," letter of 27 April 1955.

${ }^{21}$ Cf. YIVO Archive. Papers of Mendel Osherowitch. RG 725, box 2, folder 148. 
In Lestschinsky's legacy it is hard to find a clear demarcation line between scholarship and journalism: Lestschinsky-the-journalist often presented in a more popular form the studies of Lestschinsky-the-scholar. The story of his life illustrates the struggle for survival that was characteristic of virtually all Yiddish scholars of his generation. Since Yiddish scholarship had no place in Western academia, journalism often gave them a chance to earn a living, and have a forum for their ideas and the results of their research. Thus, Max Weinreich was also a regular Forverts contributor. ${ }^{22}$ Yet even if the lion's share of Lestschinsky's voluminous corpus of writings does not fully correspond to contemporary academic standards, his articles, books, and archives, surface-scratched for this overview of his life and oeuvre, represent important sources for studying Jewish history of the twentieth century.

\section{Acknowledgments}

The author thanks anonymous reviewers for their very helpful suggestions.

\section{References}

Anonymous. 1935. Der "Forverts” un der "Bund.” New York: Bundisher klub.

Anonymous. 1966. "Yakov Lestschinsky, shrayber, forsher, toyt in Yisroyel” (Jacob Lestschinsky, writer and scholar, died in Israel). Forverts (24 March):1, 13.

Auerbach, Ephraim and Moshe Starkman, eds. 1960. Leksikon fun der nayer yidisher literatur (Dictionary of Modern Yiddish Literature), vol. 3. New York: Congress for Jewish Culture.

Balberyszki, M. 1954. "Volkism and the Volks Partei." In Struggle for Tomorrow: Modern Political Ideologies of the Jewish People, edited by Basil J. Vlanianos and Feliks Gross, 236-243. New York: Arts.

Berman, P. 1956. "Yakov Lestschinsky: tsu zayn 80-yorikn yubiley" (Jacob Lestschinsky: to his 80th jubilee). Forverts (19 September):10.

Borochov, Ber. 1913. "Di oyfgabn fun der yidisher filologye." In Der pinkes: yorbukh far der geshikhte fun der yidisher literatur un shprakh, far folklore, kritik un bibliografye (The Register: Annual for History of Yiddish Literature and Language, for Folklore, Criticism and Bibliography), edited by Shmuel Niger, 1-22. Vilna: B. Kletzkin. English translation in this issue.

Borochov, Ber. 1935. Geklibene shriftn (Selected Works). Warsaw: Arbet un visn.

Cahan, Abraham. 1930. "Mayn batsiung tsum tsionism" (My Attitude to Zionism). Forverts (3 March).

Della Pergola, Sergio. 1996. "Between Science and Fiction: Notes on the Demography of the Holocaust." Holocaust and Genocide Studies 10(1):36.

Dubnov-Erlich, Sophie. 1991. The Life and Work of S. M. Dubnov. Bloomington: Indiana University Press.

Estraikh, Gennady. 2006. “'Oyb di velt-gazlonim veln zikh nit araynraysn in mayn kabinet': Shimen Dubnovs briv tsu Yakov Leshtsinski" (If the Bandits of the World Don't Invade My Study). Forverts (16 December): 17.

Fishman, David E. 2005. The Rise of Modern Yiddish Culture. Pittsburgh: University of Pittsburgh Press.

Frankel, Jonathan. 1984. Prophecy and Politics: Socialism, Nationalism, and the Russian Jews. New York: Cambridge University Press.

${ }^{22}$ In the early 1920s, Weinreich's Berlin dispatches would appear under such pseudonyms as Sarah Brener, Joseph Perl, and P. Berman (see Auerbach and Starkman 1960, 379). 
Freitag, Gabriele. 2004. Nächstes Jahr in Moskau! Die Zuwanderung von Juden in die sowjetische Metropole 1917-1932. Göttingen: Vandenboeck \& Ruprecht.

Friedman, Philip. 1956. "Praktik un teorye in gezelshaftlekhn lebn" (Practice and Theory in Social Life). Di tsukunft 61(9):406-408.

Frumkin, G. 1951. Population Change in Europe since 1939. New York: Augustus M. Kelley.

Gassenschmidt, Christoph. 1995. Jewish Liberal Politics in Tsarist Russia, 1900-14: The Modernization of Russian Jewry. Basingstoke: Macmillan.

Glikson, Paul. 1967. "Jacob Lestschinsky: A Bibliographical Survey." The Jewish Journal of Sociology 9(1):4857.

Goldberg, Nathan, Jacob Lest[s]chinsky, and Max Weinreich. 1945. The Classification of Jewish Immigrants and Its Implications: A Survey of Opinion. New York: YIVO. (The material was first published in Yiddish in YIVO Bleter, vol. 24, no. 2, Nov.-Dec. 1944).

Goldstein, Yaacov. 1998. Jewish Socialists in the United States: The Cahan Debate 1925-1926. Brighton: Sussex Academic Press.

Greyson, J. 1966. "Yakov Lestschinsky." Forverts (26 March) 1.

Hart, Mitchell B. 2000. Social Science and the Politics of Modern Jewish Identity. Stanford: Stanford University Press.

Institute of Jewish Affairs. 1942. Institute of Jewish Affairs: Its Aims and Methods. New York: Institute of Jewish Affairs.

Jacobs, Jack. 1992. On Socialists and "the Jewish Question" after Marx. New York: New York University Press.

Kahan, Arcadius. 1986. Essays in Jewish Social and Economic History. Chicago: University of Chicago Press.

Kazovsky, Hillel. 2003. The Artists of the Kultur-Lige. Jerusalem and Moscow: Gesharim and Mosty kul'tury.

Khashin, A. 1921. Problemen funem yidishn ekonomishn lebn in der ibergang-tsayt (Problems of Jewish Economic Life in the Transitional Period). Vienna: Avangard.

Krutikov, Mikhail. 2001. Yiddish Fiction and the Crisis of Modernity, 1905-1914. Stanford: Stanford University Press.

Kuznitz, Cecile Esther. 2000. "The Origins of Yiddish Scholarship and the YIVO Institute for Jewish Research.” Ph.D. diss. Stanford University.

Lestschinsky, Jacob. 1906. Der yidisher arbeter in Rusland (The Jewish Worker in Russia). Vilna: Tsukunft. The same year it appeared in Russian as Evreiskii rabochii $v$ Rossii. Vilna: n.p.

Lestschinsky, Jacob. 1907. Der yidisher arbeter in London (The Jewish Worker in London). Vilna: Tsukunft. Published also in Russian as Evreiskiy rabochiy v Londone. Moscow: Pereval.

Lestschinsky, Jacob. 1910. "Die Auswanderung der Juden nach Galveston." Zeitschrift für Demographie und Statistik der Juden 6(12):177-84.

Lestschinsky, Jacob. 1912. Gal'vestonskaya emigratsiya i emigratsionnaya politika. Kiev: Yevreyskoye emigratsionnoye obshchestvo.

Lestschinsky, Jacob. 1918a. Di yidishe oytonomye amol un haynt (Jewish Autonomy Once and Today). Kiev: Central Committee of the Fareynkte Partey.

Lestschinsky, Jacob. 1918b. Undzere natsyonale foderungen (Our National Demands). Warsaw: Tsukunft.

Lestschinsky, Jacob. 1924a. "Der kultureler khurbn in Rusland un di komunistn" (The Cultural Devastation in Russia and the Communists). Der veker (29 March).

Lestschinsky, Jacob. 1924b. "Vuhin zaynen ahingekumen di yidishe arbeter in Rusland?" (Where Did the Jewish Workers Disappear in Russia?) Der veker (12 April):9-11.

Lestschinsky, Jacob. 1924c. "Di oyfgabn fun der yidisher statistik" (The Aims at Jewish Statistics). Bleter far demografye, statistik un ekonomik 1,1 .

Lestschinsky, Jacob. 1925. Der emes vegn di yidn in Rusland (The truth about the Jews in Russia). Berlin: J. Lestschinsky.

Lestschinsky, Jacob. 1926. “A meynung vegn der yidisher kolonizatsye in Rusland” (An Opinion about the Jewish Colonization in Russia). Forverts (7 Nov.) section 2, 4.

Lestschinsky, Jacob. 1929. "Redt klore diburim!” (Speak Up!) Veker (New York) (16 Nov.):6-9. 
Lestschinsky, Jacob. 1930a. "Vilne iz itst a toyte shtot" (Vilna is a Dead Town Now). Forverts (30 March):3.

Lestschinsky, Jacob. 1930b. "Men kon zikh filn fray in goles, un golesdik in erets-yisroel” (One Can Feel Free in Exile (Diaspora) and Exiled in Palestine). Naye folkstsayting (11 Apr.):5; (18 Apr.):5.

Lestschinsky, Jacob. 1930-1931. "Di ekonomishe lage fun yidn in Poyln" (The Economic Situation of Jews in Poland). Virtshaft un lebn (1930) 4:12-32; 5:12-37; (1931) 1:1-17; 2:1-20. In 1931, this work came out in Berlin in book form.

Lestschinsky, Jacob. 1931a. "Wilna, der Niedergang einer jüdischen Stadt, ”Jüdische Wohlfahrtspflege und Sozialpolitik 1:21-33.

Lestschinsky, Jacob. 1931b. "Shimen Dubnov un der yidisher gezelshaftlekher gedank" (Simon Dubnov and the Jewish Social Thinking). Di sthukunft 36(2):123-9.

Lestschinsky, Jacob. 1932a. "Wandlungen im Leben der Juden Sowjetrusslands." Menorah, 1-2, 48.

Lestschinsky, Jacob. 1932b. "Fun der redaktsye" (Editorial). Ekonomishe shriftn 2:1-6

Lestschinsky, Jacob. 1933a. "Forverst-korespondent Leshtsinski dertseylt vi azoy di hitleristn hobn im arestirt" (The Forverts Correspondent Lestschinsky Tells How He Was Arrested by the Hitlerists). Forverts (13 Apr.):4, 8.

Lestschinsky, Jacob. 1933b. "Geto un vanderung in yidishn lebn" (Ghetto and Migration in Jewish Life). YIVO Bleter 5(1):1-6.

Lestschinsky, Jacob. 1936a. "Der eyntsiker oysveg far a groysn teyl fun di poylishe yidn, iz oystsuvandern" (Emigration is the Only Way Out for Many Polish Jews). Forverts (10 June):3, 9.

Lestschinsky, Jacob. 1936b. "Yidn loyfn fun Poyln; Polyakn kumen tsurik" (Jews Run from Poland; Poles Come Back). Forverts (25 July):10.

Lestschinsky, Jacob. 1936c. "10 milyon yidn lebn nokh mit laytn glaykh; ober di iberike zeks milyon -" (Ten million jews continue to live as equal citizens; but the other six million -). Forverts (18 August):2, 3 .

Lestschinsky, Jacob. 1937a. "Undzere oyfgabes un tsiln" (Our Aims and Objectives). Di yidishe ekonomik $1, \mathrm{I}$.

Lestschinsky, Jacob. 1937b. "Erets-yisroel un antisemitizm" (Palestine and Antisemitism). Dos naye vort (14 May):6.

Lestschinsky, Jacob. 1937-1938. "Vegn a konstruktivn plan far di poylishe yidn" (Concerning a Constructive Plan for the Polish Jews). Di yidishe ekonomik 4-5:129-148; 1-2:1-17; 3-4: 97-115.

Lestschinsky, Jacob. 1939. "Ershte ayndrukn fun amerikaner yidntum” (First Impressions After Seeing the American Jewry). Der yidisher kemfer (16 June):8-9.

Lestschinsky, Jacob. 1941. Dos sovetishe yidntum: zayn fargangenhayt un kegnvart (The Soviet Jewry: Its Past and Present). New York: Yidisher kemfer.

Lestschinsky, Jacob. 1942. "Ben-Adir." Der yidisher kemfer (4 Dec.):7-8.

Lestschinsky, Jacob. 1944. Di yidishe katasrofe: di metodn fun ir forshung (The Jewish Catastrophe: The Methods of Researching It). New York: Institute of Jewish Affairs.

Lestschinsky, Jacob. 1948. Crisis, Catastrophe and Survival: A Jewish Balance Sheet, 1914-1948. New York: Institute of Jewish Affairs.

Lestschinsky, Jacob. 1951a. "Dr. Yulius Brutskus." Forverts (15 May):4.

Lestschinsky, Jacob. 1951b. Erev khurbn: fun yidishn lebn in Poyln, 1935-1937 (On the Eve of the Holocaust: From Jewish Life in Poland, 1935-1937). Buenos Aires: Tsentral-farlag fun poylishe yidn in Argentine.

Lestschinsky, Jacob. 1952. The Position of the Jewish People Today. New York: Institute of Jewish Affairs.

Lestschinsky, Jacob. 1955. Dos natsyonale ponem fun goles-yidntum (The National Profile of Diaspora Jewry). Buenos Aires: Poale Zion Hitahdut.

Lestschinsky, Jacob. 1963. "Dubnov's Autonomism and His 'Letters on Old and New Judaism'.” In Simon Dubnov: The Man and His Work, edited by Aaron Steinberg, 76-91. Paris: French Section of the World Jewish Congress.

Lestzinsky, Jacob. 1913. "Zür Psychologie des jüdischen Auswanderers.” Zeitschrift für Demographie und Statistik der Juden 9(5):75-80. 
Manor, Alexander. 1961. Ya'akov Leshtsinski: ha-hogeh vaha-hoker (Jacob Lestschinsky: The Man and His Work). Jerusalem: World Jewish Congress.

Manor, Alexander. 1962. "Jacob Lestschinsky - on His Eighty-fifth Birthday." Jewish Journal of Sociology 4(1):101-6.

Meisel, Nakhman. 1926. "Yakov Lestschinsky: tsu zayn 50tn geburts-tog." Literarishe bleter (17 February):610-611.

Mendelsohn, Ezra. 1970. Class Struggle in the Pale: The Formative Years of the Jewish Workers' Movement in Tsarist Russia. Cambridge: Cambridge University Press.

New York Times. 1933a. "Asks Berlin Report in Leschinsky Case." (14 March):13.

New York Times. 1933b. "Writer Attacks Germany.” (26 March):28.

New York Times. 1945. "6,000,000 Jews Dead.” (8 January):17.

Osherowitch, Mendel. 1957. "Briv tsvishn Ab. Kahan un Sholem Ash vegn shrayber un 'Bund"” (Correspondence Between Ab. Cahan and Sholem Asch on Writers and the Bund). Forverts (3 August):8.

Patkin, A. L. 1947. The Origins of the Russian-Jewish Labour Movement. Melbourne: F. W. Cheshire Pty.

Rafalsky, Marcos. 1946. Tsvishn tsvey velt-milkhomes: di goyrl-yorn 1918-1945 (Between Two World Wars: The Years 1918-1945). Buenos Aires: Yubiley-komitet.

Rakovsky, Puah. 2002. My Life as a Radical Jewish Woman: Memoirs of a Zionist Feminist in Poland, edited and with an introduction by Paula E. Hyman. Bloomington: Indiana University Press.

Reisen, Zalman. 1930. Leksikon fun der yidisher literatur, prese un filologye (Dictionary of Yiddish Literature, Press and Philology), vol. 3. Vilna: B. Kletzkin.

Rogoff, Hillel. 1940. "Di sotsyalistishe bavegung in Amerike amol un haynt" (The Socialist Movement in America Once and Nowadays). In Vikhtike problemen fun der arbeter-bavegung, 3-10. New York: Veker.

Rogoff, Hillel. 1954. Der gayst fun "Forverts": materyaln tsu der geshikhte fun der yidisher prese in Amerike (The Spirit of Forverts: Materials for the History of the Yiddish Press in America), 92-99. New York: Forverts.

Rubin, Israel. 1930. "Yakov Leshtsinski." Literarishe bleter (4 Apr.):262-3.

Shapiro, Leon. 1980. The History of ORT: A Jewish Movement for Social Change. New York: Schocken Books.

Soyer, Daniel. 2000. "Back to the Future: American Jews Visit the Soviet Union in the 1920s and 1930s." Jewish Social Studies 3(3):131.

Steinberg, Isaak N. 1954. "Territorialism." In Struggle for Tomorrow: Modern Political Ideologies of the Jewish People, edited by Basil J. Vlavianos and Feliks Gross, 112-129. New York: Arts.

Weinberg, Robert. 1998. Stalin's Forgotten Zion. Berkeley: University of California Press.

Zeller, Bernhard, ed. 1978. Alfred Döblin: Eine Ausstellung des Deutschen Literaturarchivs im SchillerNationalmuseum. Munich: Kösel in Kommission.

Zimmerman, Joshua D. 2004. Poles, Jews, and the Politics of Nationality: The Bund and the Polish Socialist Party in Late Tsarist Russia, 1892-1914. Madison: University of Wisconsin Press.

Zipperstein, Steven J. 1993. Elusive Prophet: Ahad Ha' am and the Origins of Zionism. London: Peter Halban.

Zuckerman, Baruch. 1956. "Yakov Lestschinsky a ben-shmoynim" (Jacob Lestschinsky is 80). Der yidishe kemfer (30 Nov.):13-14.

Zukerman, William. 1937. The Jew in Revolt: The Modern Jew in the World Crisis. London: Martin Secker and Warburg.

Zweig, Stefan. 1936. "Foreword." In What Will Happen to the Jews, edited by Joseph Leftwich, ix-xii. London: P.S. King. 